\title{
Indicators of oxygen- and capacity-limited thermal tolerance in the lugworm Arenicola marina
}

\author{
Astrid C. Wittmann ${ }^{1}$, Mareike Schröer ${ }^{1}$, Christian Bock $^{1}$, Hans-Ulrich Steeger ${ }^{2}$, \\ Rüdiger J. Paul' ${ }^{2}$, Hans-O. Pörtner ${ }^{1, *}$
}

${ }^{1}$ Marine Animal Physiology, Alfred Wegener Institute for Polar and Marine Research, Am Handelshafen 12, 27570 Bremerhaven, Germany

${ }^{2}$ Institute for Zoophysiology of the Westphalian Wilhelm University of Münster, Hindenburgplatz 55, 48143 Münster, Germany

\begin{abstract}
Thermal tolerance windows were investigated in lugworms Arenicola marina (L.) from the North Sea, the English Channel and the Atlantic during winter and summer seasons. We adopted the concept of oxygen- and capacity-limited thermal tolerance and tested a variety of methods for their suitability to identify characteristics of the respective thermal window, such as critical, pejus (lat.: getting worse) and optimum temperatures ( $T_{\mathrm{C}}, T_{\mathrm{p}}$ and $\left.T_{\mathrm{opt}}\right)$, as well as temperature-dependent performance. First, the effect of acute temperature changes on oxygen consumption and pumping activity was examined in artificial burrows ventilated by lugworms collected in winter and summer from North Sea mudflats (acclimation temperatures 5 and $10^{\circ} \mathrm{C}$ ). Second, the window of acutely temperaturedependent growth was evaluated by following the integration of uniformly labelled ${ }^{13} \mathrm{C}$-L-phenylalanine into proteins of the cuticulo-muscular tube, using nuclear magnetic resonance spectroscopy, possibly providing access to $T_{\mathrm{p}}$ values. Third, seasonal changes in haemoglobin half-saturation oxygen tension $\left(P_{50}\right)$ and haemoglobin oxygen status in vivo were studied in lugworms from the North Sea population. $T_{\mathrm{c}}$ values were defined by use of oxygen consumption measurements, whereas pumping activity, growth performance and tissue oxygenation allowed determination of $T_{\text {opt }}$. Our results show that the thermal window of actively ventilating lugworms is narrower in winter than in summer. The acute optimum temperature of growth performance was tilted towards the lower $T_{\mathrm{c}}$ and likely shifts with acclimation. Methods were found suitable to identify the acute thermal window of oxygen-limited thermal tolerance in the lugworm. Consecutive comparison of populations during various seasons in a latitudinal cline should thus lead to a better understanding of the impacts of climate change on marine ecosystems.
\end{abstract}

KEY WORDS: Oxygen consumption · Pumping activity · Protein synthesis · Growth performance · NMR · Tissue oxygenation

\section{INTRODUCTION}

Temperature patterns in global climate have frequently been proposed as the most important factors determining marine zoogeography (Angel 1991). Available physiological work indicates that populations of Northern Hemisphere species from different latitudes of the East Atlantic exhibit different thermal tolerance windows. Genetic and physiological differences between populations, observed in e.g. lugworm Arenicola marina and cod Gadus morhua populations along a latitudinal cline (Hummel et al. 1997, Sommer et al. 1997, Nielsen et al. 2001, Sommer \& Pörtner 2002, Lannig et al. 2003) may result from selection for optimal physiological performance under different climatic conditions. Current climate change and the associated warming trends thus cause poleward shifts in the geographical distribution of marine animal species and populations in the North Sea (Perry et al. 2005).

If we want to understand these effects of global warming we will need to identify mechanisms of temperature adaptation across levels of biological organi- 
zation (Johnston \& Bennett 1996, Pörtner et al. 2005a,b, Pörtner 2006) and their contribution to adjusting and limiting both cold and heat tolerance (e.g. Wood \& MacDonald 1997, Pörtner et al. 2001). According to ecological evidence, thermally dependent oxygen supply and associated performance levels depending on aerobic scope determine climate sensitivity of marine ectothermic animals (Pörtner \& Knust 2007), thereby supporting the previous concept of oxygen- and capacity-limited thermal tolerance (Pörtner 2001, 2002a).

The thermal tolerance window of a population is the temperature range in which individuals cannot only survive but also reproduce. Once temperature declines or increases, the animals initially reach pejus thresholds ( $T_{\mathrm{p} i}$ pejus: getting worse), where a mismatch between oxygen demand of, and supply to, the tissues causes reduced aerobic functional capacity of the organism. At more extreme (critical) temperatures $\left(T_{\mathrm{c}}\right)$, animals start to respire anaerobically and can only survive for a limited time. Warming beyond pejus thresholds already leads to the onset of reduced growth performance and to reduced abundance of fish in the field (Pörtner \& Knust 2007). Therefore, it is crucial to understand the mechanisms that set pejus thresholds if we want to understand the effects of climate change on the biogeography and performance of individual species. From a wider perspective, there is evidence that the principles of oxygen- and capacity-limited thermal tolerance are similar across animal phyla (reviewed by Pörtner 2001, 2002a,b,c).

Accordingly, oxygen-limited thermal tolerance has also been shown in intertidal eurytherms (e.g. Sommer et al. 1997, Sommer \& Pörtner 1999, 2002, Sokolova \& Pörtner 2003), among them the lugworm Arenicola marina (L.), which is a key species in structuring the intertidal zone. Temperature was an issue in early studies of the lugworm by Krüger (1964), Wells (1964), Seymour (1972) and Toulmond (1977) and has recently regained interest in studies of limiting temperature conditions and of metabolic adjustments during temperature adaptation (e.g. Schmidt et al. 1992, Hummel et al. 1997, Sommer et al. 1997). A. marina, when dwelling in a burrow in the marine sediment, experiences downward shifts of upper and lower $T_{\mathrm{c}}$ values as a result of latitudinal cold adaptation or seasonal cold acclimatisation (Sommer et al. 1997). These changes are associated with shifts in mitochondrial densities and their functional properties (Sommer \& Pörtner 2002, 2004, Keller et al. 2004). However, pejus thresholds, defined by the onset of a loss in aerobic scope, have not yet been available for A. marina or other annelids. Furthermore, although many studies address temperature-dependent oxygen binding by blood pigments, the contribution of temperature-dependent blood oxygen transport to thermal tolerance has not been analysed comprehensively in the light of the whole animal picture of oxygen-limited thermal tolerance.

The present study establishes the suitability of various measures of the thermal window of the lugworm Arenicola marina from an integrative, whole-animal point of view. Due to the crucial role of oxygen supply mechanisms, such as ventilation and circulation, in thermal tolerance, the analysis of temperaturedependent performance windows occurred in artificial burrows where lugworms relied on their own ventilatory activity for supply with oxygen-rich water. We determined oxygen consumption associated with temperature-dependent pumping activity as well as blood oxygen transport through haemoglobin oxygenation. Functional consequences for growth were addressed at the level of the protein synthesis rate. While growth studies in vivo cannot circumvent the effect of shifting acclimation temperatures, as a constraint, analysis of protein synthesis allows specification of the performance window for each individual acclimation temperature. For the present pilot study, methods were tested on individuals from different populations according to availability. This includes different seasons for the North Sea population. The present analysis builds the basis for comparisons of populations of $A$. marina in a latitudinal cline (M. Schröer et al. unpubl. data).

\section{MATERIALS AND METHODS}

\subsection{Lugworms}

Specimens of Arenicola marina (L.) were collected in March and September 2005 from intertidal flats of the North Sea near Dorum-Neufeld, Germany, at the same location as reported previously (Sommer et al. 1997, Sommer \& Pörtner 2002). Individuals collected in March were kept at the in situ water temperature of $5^{\circ} \mathrm{C}$, with the exception of a brief accidental warming pulse in May 2005, when aquarium-maintained individuals were exposed to $8^{\circ} \mathrm{C}$ for $24 \mathrm{~h}$. Lugworms collected in September were kept at $10^{\circ} \mathrm{C}$ throughout. Both groups were reared for up to $3.5 \mathrm{mo}$ in natural sediment of a flow-through system filled with natural seawater at $32 \%$ salinity and kept in a $12 \mathrm{~h}$ light:12 h dark cycle. The upper $2 \mathrm{~cm}$ of the sediment layer was replaced by fresh material from Dorum-Neufeld once every 2 to $4 \mathrm{wk}$ to prevent the lugworms from starving.

For a study of protein synthesis, Arenicola marina specimens were collected from Saint Pol de Léon (Brittany, France) in early March 2005. Water temperature was $11^{\circ} \mathrm{C}$. Specimens were transported to the Alfred Wegener Institute for Polar and Marine Research in Bremerhaven and kept in natural sediment in the 
aquaria at $10^{\circ} \mathrm{C}$ until experimentation. Individuals were dug up $1 \mathrm{~d}$ before incubation and slowly acclimated to the respective incubation temperature without sediment in order to support evacuation of the bowels.

For analyses of haemoglobin oxygenation and lugworm oxygen status, specimens of Arenicola marina were collected in 2005 in at least monthly intervals from a mudflat north of Carolinensiel (Germany) at $53^{\circ} 42.7^{\prime} \mathrm{N}, 7^{\circ} 48.1^{\prime} \mathrm{E}$. Specimens from the Atlantic coast population were collected in August 2005 in mudflats at La Hume near Arcachon, France. Transport and aquarium maintenance of specimens was carried out at temperatures and salinities resembling those of the collecting sites. Care was taken that the change of water temperature during transport was minimal. The difference in temperature for specimens arriving at the laboratory from Arcachon was $2^{\circ} \mathrm{C}$ and from Carolinensiel was $<1^{\circ} \mathrm{C}$. Lugworms were kept in natural sediment in a recirculating aquarium system at the temperature measured during collection $\pm 1.5^{\circ} \mathrm{C}$ and at a salinity of $31.0 \pm 0.5 \%$ for at least $48 \mathrm{~h}$ prior to experimentation. For an overview of locations and experimental use of the respective specimens see Table 1.

\subsection{Analyses of oxygen consumption and pumping activity}

The influence of temperature on metabolic rate and pumping activity was quantified by analyses of oxygen consumption and of the volume flow produced by the lugworms. Measurements were performed in the dark using artificial burrows. Depending on the size of each individual, lugworms were fitted into straight Plexiglas tubes with inner diameters of 6,7 , or $8 \mathrm{~mm}$. Tubes had a rough inner surface to support irrigation activity. Both openings of the tubes were closed with a finemesh fishing net to prevent the individuals from escaping. As in their natural burrows, the lugworms generated a water current to provide themselves with oxygen. Oxygen partial pressures of incurrent $\left(P_{\mathrm{IO} 2}\right.$, $\mathrm{kPa})$ and excurrent $\left(P_{\mathrm{EO} 2}, \mathrm{kPa}\right)$ water were monitored continuously by means of oxygen micro-optodes (Presens Precision Sensing $\mathrm{GmbH}$ ), one on either side of the tube. The volume flow produced by the lugworms was measured using an electromagnetic flowmeter (RT-500, Hugo Sachs Elektronik) by use of a probe of an inner diameter of $3 \mathrm{~mm}$ attached to one side of the tube, next to one of the oxygen optodes. This arrangement allowed concomitant analysis of oxygen consumption and volume flow, even when individuals reversed the water flow through their artificial burrows.

Then, $12 \mathrm{~h}$ prior to experimentation, a lugworm was dug up from the aquarium sediment and kept in a darkened container to evacuate the bowels. This prevented clogging of the experimental setup. Before and after the experiments the body fresh weight of each individual was determined (means \pm SD are given in Table 1). Experiments started at a temperature of $5^{\circ} \mathrm{C}$ for individuals collected in March and at $11^{\circ} \mathrm{C}$ for individuals collected in September. The temperature was first lowered and then elevated in a stepwise procedure at a rate of $1^{\circ} \mathrm{C} \mathrm{h}^{-1}$. Each lugworm collected in March was incubated for $9 \mathrm{~h}$ at $-1,2,5,8,11$ and $14^{\circ} \mathrm{C}$, and individuals that had encountered accidental

Table 1. Arenicola marina. Origin, time of collection and experimental use of specimens. Lugworm fresh weight values are means $\pm \mathrm{SD}$. $T_{\mathrm{c}}$ : lower critical temperature; $T_{\text {cll }}$ : upper critical temperature; $T_{\text {opt }}$ : optimum temperature; $T_{\mathrm{pl}}$ : lower pejus temperature; $T_{\mathrm{pll}}$ : upper pejus temperature

\begin{tabular}{|c|c|c|c|c|c|c|c|}
\hline Origin & $\begin{array}{l}\text { Time of } \\
\text { collection }\end{array}$ & $\begin{array}{c}\text { Temperature } \\
\text { of acclimation } \\
\left({ }^{\circ} \mathrm{C}\right)\end{array}$ & $\begin{array}{l}\text { Acclimation } \\
\text { time }\end{array}$ & $\begin{array}{l}\text { Lugworm } \\
\text { fresh weight } \\
\qquad(g)\end{array}$ & Experiments & $\begin{array}{l}\text { Experimental } \\
\text { temperatures } \\
\left({ }^{\circ} \mathrm{C}\right)\end{array}$ & $\begin{array}{l}\text { Characteristics } \\
\text { of thermal } \\
\text { window }\left({ }^{\circ} \mathrm{C}\right)\end{array}$ \\
\hline \multirow[t]{2}{*}{$\begin{array}{l}\text { North Sea } \\
\text { (Dorum-Neufeld, } \\
\text { Germany) }\end{array}$} & Mar 2005 & 5 & $2-3.5 \mathrm{mo}$ & $5.2 \pm 1.0$ & $\begin{array}{l}\text { Oxygen } \\
\text { consumption } \\
\text { and pumping } \\
\text { activity }\end{array}$ & $\begin{array}{l}-1,2,5,8,11 \\
14,17,20,23\end{array}$ & $\begin{array}{l}T_{\mathrm{CI}}<2 \\
T_{\mathrm{cII}}>8 \\
\text { After warming } \\
\text { pulse: } T_{\mathrm{CI}}<2 \\
T_{\mathrm{cII}}>17 \\
T_{\text {opt }} \approx 8\end{array}$ \\
\hline & Sep 2005 & 10 & $2.5-3 \mathrm{mo}$ & $3.2 \pm 0.9$ & $\begin{array}{l}\text { Oxygen } \\
\text { consumption }\end{array}$ & $\begin{array}{l}3,5,9,11,15 \\
18,21,24,26\end{array}$ & $\begin{array}{l}T_{\mathrm{cI}}<5 \\
T_{\mathrm{cII}}>24\end{array}$ \\
\hline $\begin{array}{l}\text { English Channel } \\
\text { (Saint Pol de } \\
\text { Léon, France) }\end{array}$ & Mar 2005 & 10 & $4-5 \mathrm{mo}$ & $6.3 \pm 1.9$ & $\begin{array}{l}\text { Protein } \\
\text { biosynthesis by } \\
\text { NMR-spectroscopy }\end{array}$ & $\begin{array}{l}4,6.3,11 \\
14.6,18.4\end{array}$ & $\begin{array}{l}T_{\mathrm{opt}} \approx 6.3 \\
T_{\mathrm{pI}} \approx 5 \\
T_{\mathrm{pII}} \approx 8\end{array}$ \\
\hline \multirow[t]{2}{*}{$\begin{array}{l}\text { North Sea } \\
\text { (Carolinensiel, } \\
\text { Germany) }\end{array}$} & $\begin{array}{l}\text { Dec } 2004 \text { to } \\
\text { Jan } 2006, \\
\text { every } 4 \text { wk }\end{array}$ & $3-20$ & $<24 \mathrm{~h}$ & $6.6 \pm 2.2$ & $\begin{array}{l}\text { Oxygen-binding } \\
\text { properties }\end{array}$ & $3-20$ & - \\
\hline & Jan 2005 & $5-7$ & $1-21 \mathrm{~d}$ & $4.2 \pm 1.2$ & In vivo spectroscopy & $5-30$ & - \\
\hline $\begin{array}{l}\text { Atlantic } \\
\text { (Arcachon, France) }\end{array}$ & Aug 2005 & 18 & $<3 d$ & $2.6 \pm 1.1$ & $\begin{array}{l}\text { Oxygen-binding } \\
\text { properties }\end{array}$ & 18 & - \\
\hline
\end{tabular}


warming were also exposed to 17,20 and $23^{\circ} \mathrm{C}$. Lugworms obtained in September were incubated at 3, 5, $9,11,15,18,21,24$ and $26^{\circ} \mathrm{C}$ for $6 \mathrm{~h}$ only. This period (approximately $4 \mathrm{~h}$ ) was sufficient for the lugworms to reach new stable values in pumping frequency and volume flow and to record the new steady state $(2 \mathrm{~h})$. Mean $P_{\mathrm{IO} 2}, P_{\mathrm{EO} 2}$ and weight-specific volume flow $\left(V_{\mathrm{w}}\right.$ $\mathrm{ml} \mathrm{h}^{-1} \mathrm{~g}^{-1}$ ) were calculated at least over the final $2 \mathrm{~h}$ of each incubation period. From these data, oxygen consumption $\left(M_{\mathrm{O} 2}, \mu \mathrm{mol} \mathrm{O}_{2} \mathrm{~h}^{-1} \mathrm{~g}^{-1}\right)$ and the efficiency of oxygen extraction, $V_{\mathrm{w}} / M_{\mathrm{O} 2}, \mathrm{ml}\left(\mu \mathrm{mol} \mathrm{O}_{2}\right)^{-1}$ were determined. The pumping frequency $\left(\mathrm{min}^{-1}\right)$ and water volume transported per peristaltic wave of the body wall musculature (wave volume, $\mathrm{ml}$ ) were calculated from volume flow recordings during 3 to 10 ventilation periods.

\subsection{Analysis of protein biosynthesis by NMR spectroscopy}

We used uniformly labelled ${ }^{13} \mathrm{C}$-L-phenylalanine for the determination of protein biosynthesis following the principles outlined by Langenbuch et al. (2006). Briefly, ${ }^{13} \mathrm{C}$-L-phenylalanine was dissolved in filtered seawater $\left(75 \mathrm{mmol} \mathrm{l}^{-1}\right)$. After determining the fresh weight of the lugworms, the solution was injected at $40 \mathrm{\mu l} \mathrm{g}^{-1}$ body weight into the coelomic cavity of the lugworms by use of a disposable syringe. The lugworms were then inserted into artificial burrows and incubated at temperatures of $4,6.3,11,14.6$ and $18.4^{\circ} \mathrm{C}$ while they were ventilating their burrows. At each temperature the experiment was carried out with 8 individuals, which were exposed to incubation temperatures for $24 \mathrm{~h}$, then injected and incubated for another $30,60,90,120,150,180,240$ and $300 \mathrm{~min}$, respectively.

After the respective incubation time, head and tail regions of the lugworms were cut off, the trunk was dissected longitudinally, all inner organs were removed and the cuticulo-muscular tube was frozen in liquid nitrogen using a Wollenberger clamp. The samples were stored under liquid nitrogen until extraction.

The frozen tissue was ground under liquid nitrogen and extracted with $3 \mathrm{ml} 15 \%$ TCA (trichloroacetic acid) $\mathrm{g}^{-1}$ tissue powder weight by homogenisation for $2 \mathrm{~min}$ at $360 \mathrm{~W}$ using a Branson Sonifier 450. The homogenate was centrifuged for $10 \mathrm{~min}$ at $6000 \times g$ and $0^{\circ} \mathrm{C}$. Supernatant and pellet were treated differently.

The supernatant representing the cytosolic fraction containing low molecular weight constituents was neutralised with $5 \mathrm{M} \mathrm{KOH}$ and dried using a Bachofer Vacuum Concentrator with a Heto Cooling Trap. The dried residue was dissolved in $3 \mathrm{ml} \mathrm{D}_{2} \mathrm{O}$ (deuterium oxide) $\mathrm{g}^{-1}$ tissue powder weight. The pellet was washed twice with TCA, suspended in distilled water and neu- tralised with $5 \mathrm{M} \mathrm{KOH}$. After centrifugation (10 min, $6000 \times g, 0^{\circ} \mathrm{C}$ ), the supernatant containing water-soluble proteins was removed and stored while the pellet was boiled in a water bath for 20 min with $3 \mathrm{ml} 1 \mathrm{M}$ $\mathrm{NaOH} \mathrm{g}{ }^{-1}$ tissue powder weight. After centrifugation $\left(10 \mathrm{~min}, 6000 \times g, 20^{\circ} \mathrm{C}\right.$ ), the supernatant containing water-insoluble proteins was added to the water-soluble protein fraction and both were dried using the Bachofer Vacuum Concentrator with Heto Cooling Trap. The total protein was dissolved in $3 \mathrm{ml} \mathrm{D}_{2} \mathrm{O} \mathrm{g}^{-1}$ tissue powder weight.

Both cytosolic and protein extracts were measured in a Bruker 9.4 T Avance NMR Spectrometer at frequencies of $400 \mathrm{MHz}$ for proton spectra and 100.6 MHz for ${ }^{13} \mathrm{C}$ spectra. A $5 \mathrm{~mm}{ }^{1} \mathrm{H} / \mathrm{BBI}$ probe was used, and the following parameters were applied-for ${ }^{1} \mathrm{H}$ : 64 scans, flip angle $90^{\circ}$, relaxation delay $11.0 \mathrm{~s}$, spectral width $8250 \mathrm{~Hz}$, data size $64 \mathrm{~K}$; for ${ }^{13} \mathrm{C}$ : 6100 scans for cytosolic extracts, 16400 scans for protein fractions, flip angle $90^{\circ}$, relaxation delay $2.0 \mathrm{~s}$, spectral width $24000 \mathrm{~Hz}$, data size $64 \mathrm{~K}$, composite pulse decoupling. The protein contents of the protein extracts were quantified according to Bradford (1976).

The amount of incorporated ${ }^{13} \mathrm{C}$-L-phenylalanine was obtained by integration of the peak areas assigned to ${ }^{13} \mathrm{C}$-L-phenylalanine in the ${ }^{13} \mathrm{C}$ spectrum referring to a standard solution of the pure substance. For each spectrum, only the peak originating from the phenyl group within the phenylalanine molecule was evaluated because the other peaks, which are generated by only 1 nucleus, show a high proportion of naturally occurring ${ }^{13} \mathrm{C}$, whereas the probability of a multilabelled phenyl group is very low in nature. The calculated amount of incorporated ${ }^{13} \mathrm{C}$-L-phenylalanine was related to the respective protein content of the sample and plotted against incubation temperature for each incubation time. In Fig. 3, the short incubation periods of 30 to 120 min were grouped for the first data point, and the second data point at each temperature arises from analyses carried out after longer incubation times of 150 to $300 \mathrm{~min}$.

\subsection{Haemoglobin oxygen-binding properties}

An oxygen diffusion chamber technique (KroghRasmussen \& Weber 1979) was used to investigate the oxygen-binding properties of the haemoglobin molecule during the course of $1 \mathrm{yr}$. Effects of $\mathrm{pH}$ or modulators of the oxygen-binding curve, such as inorganic ions, were eliminated by separation of haemoglobin from the blood plasma by Microcon YM-100 centrifugal devices (Millipore) and resuspension in $10 \mathrm{mmol}^{-1}$ HEPES buffer at $\mathrm{pH}$ 7.5. A spectrophotometer (U-1100, Hitachi) was used to record the absorption of $5 \mu \mathrm{l}$ sub- 
samples placed as a thin layer inside a thermostatted flowthrough chamber. The oxygen partial pressure of the gas flow in the chamber could be modulated in $1 \%$ steps by mixing room air and nitrogen with a gas mixing pump (2M303/a-f, Wösthoff). Isolated haemoglobin of Arenicola marina tends to dissociate into its subunits even at slightly alkaline $\mathrm{pH}$ (Rousselot et al. 2006). Therefore, and since the partial pressure of carbon dioxide could not be controlled by this setup, $\mathrm{pH}$ changes in the haemoglobin solution were minimized by diluting $0.5 \mu \mathrm{l}$ samples 10 -fold in $1 \mathrm{~mol} \mathrm{l}^{-1}$ HEPES buffer at $\mathrm{pH}$ 7.0. Measurements were carried out at neutral $\mathrm{pH}$ to shift the oxygen-dissociation curve to the right and to match the characteristics of the diffusion chamber. The results were then converted to the temperatures and blood-pH values at the time of lugworm collection using an apparent heat of oxygenation $(\Delta H)$ value of $-22 \mathrm{~kJ} \mathrm{~mol}^{-1}$ (Mangum 1978), a Bohr shift value $\left(\Delta \log P_{50} / \Delta \mathrm{pH}\right)$ of -0.9 (Weber 1978) and a temperature sensitivity of $\mathrm{pH}\left(\Delta \mathrm{pH} /{ }^{\circ} \mathrm{C}\right)$ of -0.013 (Mangum 1978).

\subsection{In vivo spectroscopy}

The apparent oxygenation status of living lugworms was investigated by use of an in vivo spectroscopy technique. Lugworms were kept in transparent and perforated Plexiglas tubes, perfused by seawater of controlled temperature and oxygen partial pressure. A halogen cold light lamp (KL 150B, Schott) equipped with a fibre optic light guide served as a light source. The spectral composition of this lamp, as well as the absorption spectra of the lugworms' tissues, were recorded by a multichannel microspectralphotometer (MMS-UV/VIS-Modul, Carl Zeiss). After subtraction of a normalized lamp spectrum, a measure of oxygenation could be derived from whole-animal absorption spectra. Hence, a ratio of an oxygen-dependent and an oxygen-independent wavelength integral was calculated with the oxygen-dependent absorption pattern of haemoglobin being prominent in the whole-animal spectra. Because the contribution to the spectrum by other heme pigments like myoglobin and the cytochromes is not exactly known, the term 'apparent oxygenation status' is used throughout the text.

\subsection{Statistics}

Significant patterns in the temperature dependence of oxygen consumption rates $\left(M_{\mathrm{O} 2}\right)$, of water volume requirements for oxygen supply $\left(V_{\mathrm{w}} / M_{\mathrm{O} 2}\right)$, of mean oxygen partial pressures in exhalant water $\left(P_{\mathrm{EO} 2}\right)$ and of ${ }^{13} \mathrm{C}$-phenylalanine incorporation were evaluated by analysis of variance (ANOVA) and post hoc Tukey's HSD-test. The difference in $M_{\mathrm{O} 2}$ at the control temperature $\left(5^{\circ} \mathrm{C}\right)$ of the 2 groups of investigated North Sea lugworms was analysed by Student's $t$-test. This test was also applied to check for significant deviations of $M_{\mathrm{O} 2}$ from values extrapolated from the exponential $Q_{10}$ dependent curve in North Sea winter and summer individuals. The Mann-Whitney $U$-test was used to determine whether pumping frequencies and wave volumes differed between temperature steps. Statistical significance was identified at the $\mathrm{p} \leq 0.05$ level. Data obtained in the first group of individuals $(\mathrm{n}=2)$ are given as means \pm deviation from the mean. All other data are given as means \pm SE if not stated otherwise. Statistical analyses were carried out by use of STATISTICA (Statsoft). Regressions were fitted and analysed by use of Sigmaplot 8.0.

\section{RESULTS}

\subsection{Metabolic rate and pumping activity}

The influence of temperature on metabolic rate was first investigated in 2 lugworms Arenicola marina exposed to water temperatures of between -1 and $14^{\circ} \mathrm{C}$. These individuals had been collected from the North Sea in early March and maintained at $5^{\circ} \mathrm{C}$. After these 2 individuals had been examined, a transient warming pulse in the rearing system led to brief exposure of the remaining lugworms to $8^{\circ} \mathrm{C}$ for $24 \mathrm{~h}$ in May 2005. Thereafter, acclimation to $5^{\circ} \mathrm{C}$ continued. For individuals exposed to the warming pulse, the temperature range to be analysed was broadened to between -1 and $23^{\circ} \mathrm{C}$ due to their largely elevated metabolic rate and reduced sensitivity to warming.

When temperature was lowered, the respiration rate of the first 2 individuals decreased slightly from $0.41 \pm$ $0.09 \mu \mathrm{mol} \mathrm{O} \mathrm{h}^{-1} \mathrm{~g}^{-1}$ at $5^{\circ} \mathrm{C}$ to $0.27 \pm 0.12 \mu \mathrm{mol} \mathrm{O} \mathrm{O}^{-1}$ $\mathrm{g}^{-1}$ at $2^{\circ} \mathrm{C}$ (values are means \pm mean deviation; Fig. 1 , triangles). At $-1^{\circ} \mathrm{C}$ metabolic rate increased and reached similar values as at acclimation temperature $\left(0.55 \pm 0.14 \mu \mathrm{mol} \mathrm{O} \mathrm{O}_{2} \mathrm{~h}^{-1} \mathrm{~g}^{-1}\right)$. Upon warming, oxygen consumption rose exponentially at an extremely high $Q_{10}$-value of $15.29 \pm 5.86$ (temperature range: 2 to $8^{\circ} \mathrm{C}$ ) and reached a maximum rate of $1.21 \pm 0.26 \mu \mathrm{mol} \mathrm{O}_{2} \mathrm{~h}^{-1}$ $\mathrm{g}^{-1}$ at $8^{\circ} \mathrm{C}$. An exponential curve following the equation $M_{\mathrm{O} 2}=0.23+0.01 \times \mathrm{e}^{0.55 \mathrm{~T}}$ fitted the data best at $\mathrm{R}^{2}$ $=0.85$. Beyond $8{ }^{\circ} \mathrm{C}$, respiration rate decreased progressively to a value of $0.73 \pm 0.32 \mu \mathrm{mol} \mathrm{O}_{2} \mathrm{~h}^{-1} \mathrm{~g}^{-1}$ at $14^{\circ} \mathrm{C}$. Although the value of these results is constrained by small sample size, they contrast so much with the consecutive dataset obtained from the same population after the warming pulse that we decided to keep those data as preliminary information and a 


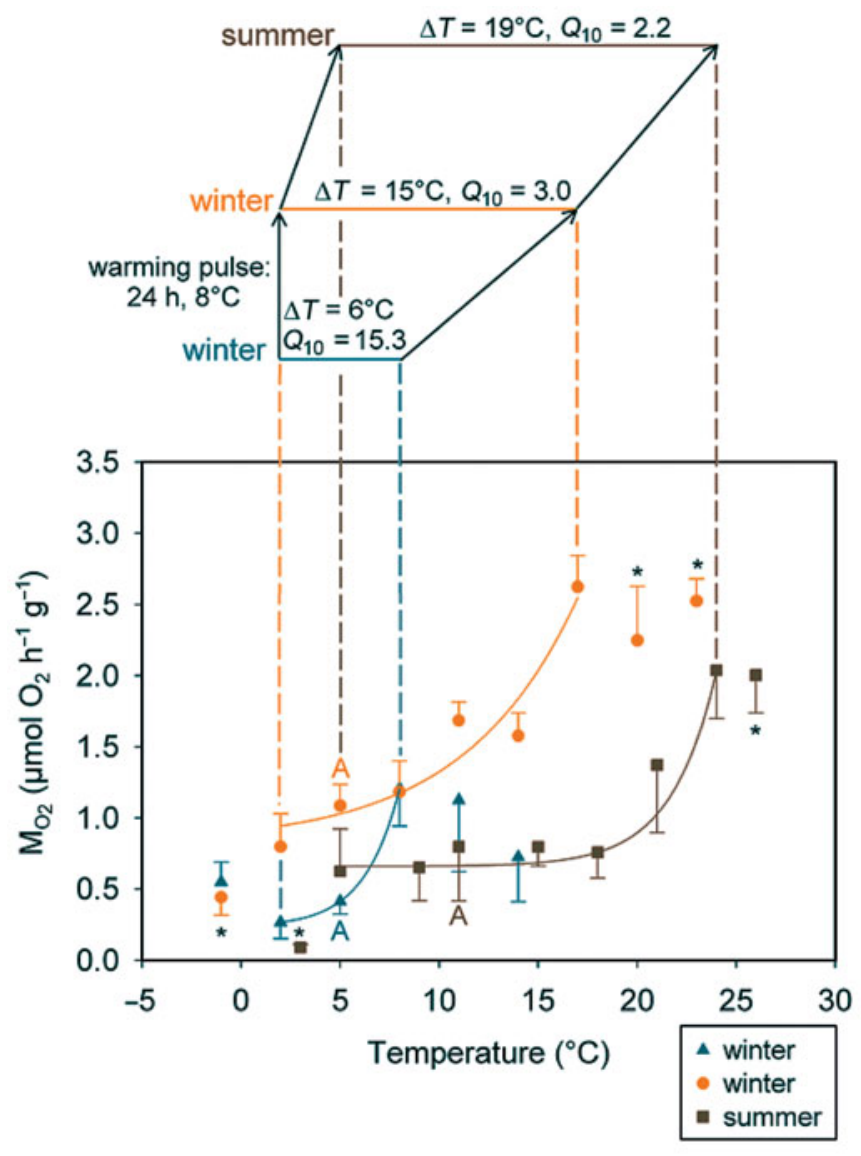

Fig. 1. Arenicola marina. Oxygen consumption $\left(M_{\mathrm{O} 2}, \mu \mathrm{mol} \mathrm{O}_{2}\right.$ $\mathrm{h}^{-1} \mathrm{~g}^{-1}$ ) of lugworms from the North Sea (Dorum-Neufeld, Germany), acclimated to $5^{\circ} \mathrm{C}$ (collected in early March) and $10^{\circ} \mathrm{C}$ (collected in September). Oxygen consumption values at, or very close to, the acclimation temperature are labelled by the letter A. Accidental warming of winter specimens $\left(8^{\circ} \mathrm{C}\right.$, $24 \mathrm{~h}$ ) led to a significant rise in metabolic rate at acclimation temperature and increased tolerance to warming. After summer acclimatisation lugworms exhibited an even wider thermal window, but lost cold tolerance. $\Delta$ : winter specimens, $\mathrm{n}=$ 2 , values are means \pm range; $\bullet$ : winter specimens from the same stock after being exposed to the warming pulse, $\mathrm{n}=4$ to 5 , values are means $\pm \mathrm{SE}$ : : summer specimens, $\mathrm{n}=3$ to 5 , values are means $\pm \mathrm{SE}^{*}{ }^{*}$ : significantly different from values extrapolated from respective exponential curve fit

perspective on the impact of the transient warming pulse.

Lugworms investigated between $3 \mathrm{~d}$ and 4 wk after transient warming showed a significant, long-term increment in oxygen consumption (Fig. 1, circles). When these lugworms were exposed to temperatures as low as $-1^{\circ} \mathrm{C}$, their respiration rate dropped from $1.09 \pm 0.15 \mu \mathrm{mol} \mathrm{O}_{2} \mathrm{~h}^{-1} \mathrm{~g}^{-1}$ at $5^{\circ} \mathrm{C}$ to $0.44 \pm 0.12 \mu \mathrm{mol} \mathrm{O}$ $\mathrm{h}^{-1} \mathrm{~g}^{-1}$ (values are means $\pm \mathrm{SE}$ ). Increasing temperatures led to a significant exponential rise in oxygen consumption to a maximum value of $2.62 \pm 0.22 \mu \mathrm{mol}$ $\mathrm{O}_{2} \mathrm{~h}^{-1} \mathrm{~g}^{-1}$ at $17^{\circ} \mathrm{C}$. Further warming did not result in a further increase of metabolic rate. In the temperature range of 2 to $17^{\circ} \mathrm{C}$, respiration rose exponentially following a $Q_{10}$ of $2.97 \pm 0.88$. The equation $M_{\mathrm{O} 2}=0.82+$ $0.087 \times \mathrm{e}^{0.18 \mathrm{~T}}$ ( $\mathrm{T}$ : temperature) fitted the data best at $\mathrm{R}^{2}=0.61$. The metabolic rate at $-1,20$ and $23^{\circ} \mathrm{C}$ differed significantly from values extrapolated from the equation for these temperatures.

The oxygen consumption of lugworms collected from the North Sea in September remained more or less constant between 5 and $18^{\circ} \mathrm{C}$ (Fig. 1, squares). This group of individuals exhibited a rather drastic decrease in metabolic rate when cooled from 5 to $3^{\circ} \mathrm{C}(0.09 \pm 0.02 \mu \mathrm{mol}$ $\mathrm{O}_{2} \mathrm{~h}^{-1} \mathrm{~g}^{-1}$, compared to e.g. $0.80 \pm 0.38 \mu \mathrm{mol} \mathrm{O} \mathrm{O}^{-1} \mathrm{~g}^{-1}$ at $11^{\circ} \mathrm{C}_{i}$ Fig. 1 , squares). When the individuals were warmed, oxygen demand increased to a maximum of $2.03 \pm 0.34 \mu \mathrm{mol} \mathrm{O}_{2} \mathrm{~h}^{-1} \mathrm{~g}^{-1}$ at $24^{\circ} \mathrm{C}$ and remained unchanged upon further warming. In the temperature range from 5 to $24^{\circ} \mathrm{C}$, the $Q_{10}$ of oxygen consumption was $2.21 \pm 0.56$ and the equation $M_{\mathrm{O} 2}=0.65+3.83 \times$ $10^{-5} \times \mathrm{e}^{0.44 \mathrm{~T}}$ described the data best at $\mathrm{R}^{2}=0.52$. The values at 3 and $26^{\circ} \mathrm{C}$ differed significantly from the respective values extrapolated from the equation.

The pumping frequency of lugworms collected in March from the North Sea (post-warming pulse) decreased progressively and significantly with falling temperature from a control value of $2.49 \pm 0.08 \mathrm{~min}^{-1}$ at $5^{\circ} \mathrm{C}$ to $0.80 \pm 0.06 \mathrm{~min}^{-1}$ at $-1^{\circ} \mathrm{C}$ (Fig. 2a). At temperatures between 8 and $20^{\circ} \mathrm{C}$, the pumping frequency was significantly higher than at acclimation temperature. Values in this temperature interval ranged between $2.90 \pm 0.10$ and $3.34 \pm 0.11 \mathrm{~min}^{-1}$ and were not significantly different from each other. Only when temperature was increased to the maximum at $23^{\circ} \mathrm{C}$, did individuals raise their pumping frequency again to $4.24 \pm$ $0.14 \mathrm{~min}^{-1}$. This value was not only significantly different from the value found at $5^{\circ} \mathrm{C}$, but also from the plateau values between 8 and $20^{\circ} \mathrm{C}$. The water volume pumped by each contraction wave of the body wall musculature comprised a minimum value of $0.18 \pm$ $0.01 \mathrm{ml}$ at $8^{\circ} \mathrm{C}$, which was a significant decrease compared to $5^{\circ} \mathrm{C}(0.25 \pm 0.01 \mathrm{ml}$, Fig. $2 \mathrm{~b})$. The highest values significantly different from those at acclimation temperature were reached at $-1{ }^{\circ} \mathrm{C}(0.43 \pm 0.04 \mathrm{ml})$ and at temperatures $>14^{\circ} \mathrm{C}$. The $V_{\mathrm{w}} / M_{\mathrm{O} 2}$ ratio shows a similar picture with a minimum of $4.34 \pm 0.34 \mathrm{ml}(\mu \mathrm{mol}$ $\left.\mathrm{O}_{2}\right)^{-1}$ at $8^{\circ} \mathrm{C}$ and a tendency towards higher values of approximately $6 \mathrm{ml}\left(\mu \mathrm{mol} \mathrm{O}_{2}\right)^{-1}$ at temperatures $<5^{\circ} \mathrm{C}$ and $>17^{\circ} \mathrm{C}$ (Fig. 2c). Although there was no significant temperature dependence of the oxygen partial pressure in the exhalant water, a trend to falling values with rising temperature was observed (Fig. 2d). At $17^{\circ} \mathrm{C}$ the mean $P_{\mathrm{EO} 2}$ dropped below the critical oxygen tension $\left(P_{\mathrm{c}}\right.$ of 4 to $\left.6 \mathrm{kPa}\right)$, where oxygen supply becomes insufficient and anaerobic metabolism sets in (Schöttler et al. 1983). 


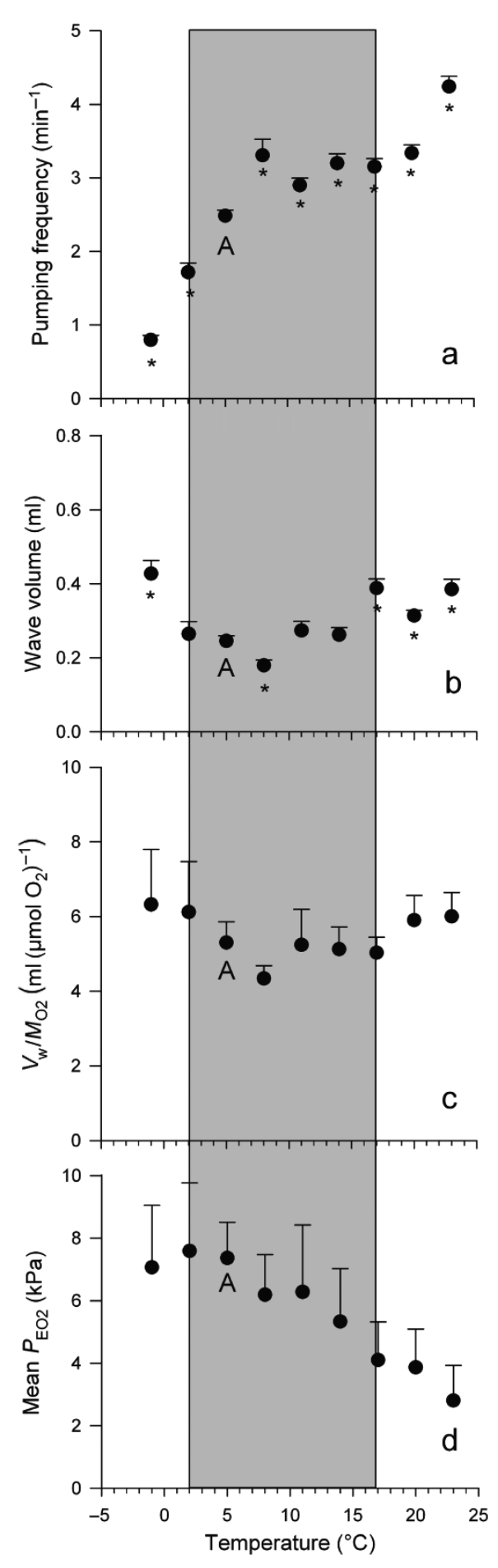

Fig. 2. Arenicola marina. (a) Pumping frequency $\left(\mathrm{min}^{-1}\right)$, (b) wave volume $(\mathrm{ml}),(\mathrm{c}) V_{\mathrm{w}} / M_{\mathrm{O} 2}\left(\mathrm{ml}(\mu \mathrm{mol} \mathrm{O})^{-1}\right)$ and $(\mathrm{d})$ mean oxygen partial pressure of the excurrent water $\left(P_{\mathrm{EO} 2}, \mathrm{kPa}\right)$ as a function of temperature in lugworms from the North Sea (Dorum-Neufeld, Germany), collected in early March and acclimated to $5^{\circ} \mathrm{C}$ after an accidental warming pulse $\left(8^{\circ} \mathrm{C}, 24 \mathrm{~h}\right)$. The grey area highlights the temperature range in which respiration rises exponentially. Values are means + SE. A: acclimation temperature ${ }^{*}$ : significantly different from acclimation temperature

\subsection{Protein biosynthesis}

${ }^{13} \mathrm{C}$-L-phenylalanine injected into the coelomic fluid is absorbed into the cytosol of the body wall muscle cells. Within the first $150 \mathrm{~min}$ after injection of the flooding dose, the cytosolic uptake of ${ }^{13} \mathrm{C}$-L-phenylalanine was more or less linear and levelled off thereafter. Saturation of the intracellular phenylalanine pool was

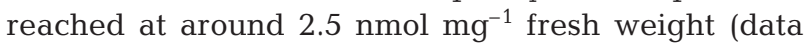
not shown).

${ }^{13} \mathrm{C}$-L-phenylalanine was incorporated into all newly synthesised proteins of the body wall. This was confirmed by a progressive increase of ${ }^{13} \mathrm{C}$-L-phenylalanine signals in the ${ }^{13} \mathrm{C}$-NMR spectra of protein extracts with incubation time. Fig. 3 shows the ${ }^{13} \mathrm{C}$-L-phenylalanine content of the body wall protein $\left(\mathrm{nmol}^{13} \mathrm{C}\right.$-phe $\mathrm{mg}^{-1}$ protein) grouped for short incubation periods (30 to $120 \mathrm{~min}$, open circles) and for long incubation periods (150 to $300 \mathrm{~min}$, filled circles) plotted against incubation temperature. At 14.6 and $18.4^{\circ} \mathrm{C}$, no increase was detectable between short- and long-term incubations. This indicates that no protein synthesis took place and that the value of around $6 \mathrm{nmol}{ }^{13} \mathrm{C}$-phe $\mathrm{mg}^{-1}$ protein obtained under all conditions should reflect the natural abundance of ${ }^{13} \mathrm{C}$-phe, including potential impurities during the extraction procedure. At $4{ }^{\circ} \mathrm{C}$, a small increase in ${ }^{13} \mathrm{C}$-phe content over time was detected, but both values resulted close to the baseline value of $6 \mathrm{nmol}{ }^{13} \mathrm{C}$-phe $\mathrm{mg}^{-1}$ protein, and, accordingly, protein synthesis can be considered mini-

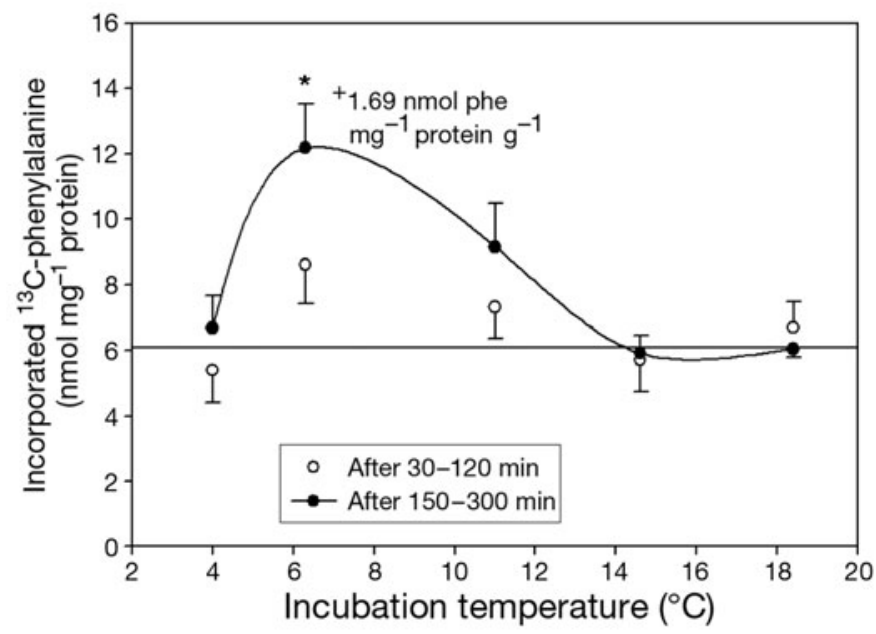

Fig. 3. Arenicola marina. Amount of incorporated ${ }^{13} \mathrm{C}$-phenylalanine (nmol mg ${ }^{-1}$ protein, means $\pm \mathrm{SE}$ ) into protein of the cuticulo-muscular tube of lugworms, dependent on incubation temperature. Specimens were collected at Saint Pol de Léon (Brittany, France) in early March 2005 and long-term acclimated to $10^{\circ} \mathrm{C}$. (O) amount of incorporated ${ }^{13} \mathrm{C}$-phenylalanine after 30 to 120 min of incubation; $(\bullet)$ amount after 150 to $300 \mathrm{~min}, \mathrm{n}=4^{*}{ }^{*}$ : significantly higher than all values at $4,14.6$ and $18.4^{\circ} \mathrm{C}$ and the value for short incubation times at $11^{\circ} \mathrm{C}_{i}{ }^{+}$: value of maximum protein biosynthesis rate $\left(\mathrm{nmol}{ }^{13} \mathrm{C}\right.$-phe $\mathrm{mg}^{-1}$ protein $\left.\mathrm{h}^{-1}\right)$ 
mal. At 6.3 and $11^{\circ} \mathrm{C}$, however, the level of incorporated ${ }^{13} \mathrm{C}$-L-phenylalanine already resulted in above baseline values after short-term incubation and rose further until later sampling. A maximum value of $12.2 \mathrm{nmol}{ }^{13} \mathrm{C}$-phe $\mathrm{mg}^{-1}$ protein was reached at $6.3^{\circ} \mathrm{C}$ after long incubation times, which was significantly higher than all levels found at $4,14.6$ and $18.4^{\circ} \mathrm{C}$, as well as after short-term incubation at $11^{\circ} \mathrm{C}$. As a result, the incorporation of labelled amino acids occurred faster at 6.3 and $11^{\circ} \mathrm{C}$ than at $4,14.6$ and $18.4^{\circ} \mathrm{C}$.

\subsection{Temperature-dependent pigment oxygen status in vivo and in vitro}

Differences in seasonal acclimatisation are reflected in significant seasonal shifts of haemoglobin properties (Figs. $4 \& 5$ ), showing that haemoglobin functional properties change with shifting thermal windows depending on the season. A shift in the relative contribution of haemoglobin subunits in Arenicola marina during the seasonal cycle has been documented by 2-dimensional gel electrophoresis (data not shown). The changing subunit composition over the year results in significant fluctuations of seasonally dependent oxygen-binding properties (Fig. 4).

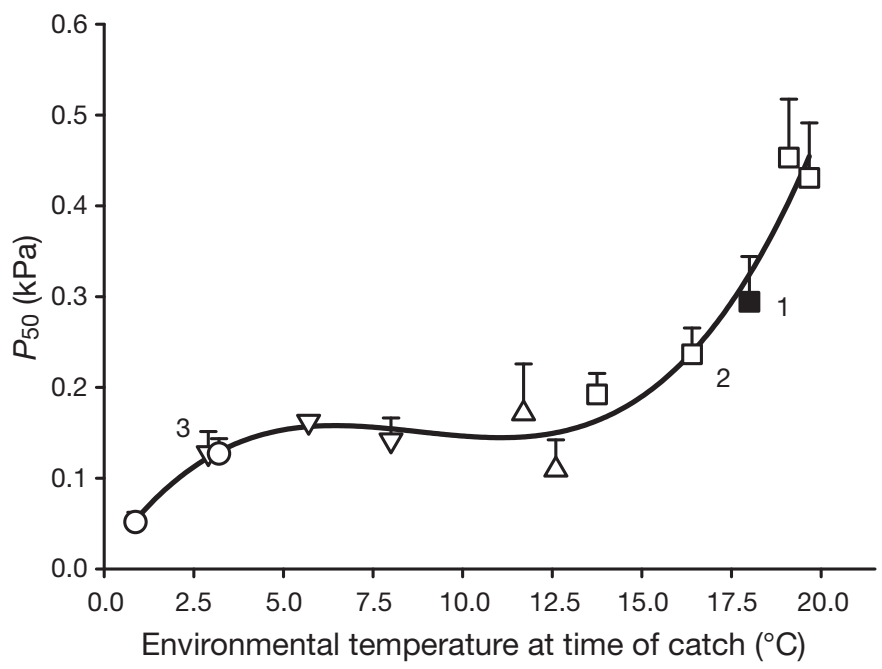

Fig. 4. Arenicola marina. Significant seasonal patterns of oxygen affinity $\left(P_{50}\right)$ of isolated lugworm haemoglobin depending on environmental temperatures at the time of catch. $P_{50}$ was measured in buffered plasma (HEPES, $1 \mathrm{~mol} \mathrm{l}^{-1}$ ) at $\mathrm{pH} 7.0$ and $20^{\circ} \mathrm{C}$. Values were then converted to $\mathrm{pH} 7.4$ and environmental temperatures using a Bohr factor of -0.9 (Weber 1978) and the apparent heat of oxygenation of $-22 \mathrm{~kJ} \mathrm{~mol}^{-1}$ (Mangum 1978). Ambient temperatures were measured at a sediment depth of $20 \mathrm{~cm}$. The figure shows means $+1 \mathrm{SD}$ of 3 or more individuals $(1: \mathrm{n}=8 ; 2: \mathrm{n}=4 ; 3: \mathrm{n}=8)$. Open symbols: individuals from Carolinensiel, Germany; closed symbol: individuals from Arcachon, France; (O): measurements in winter; $(\Delta)$ those in spring; ( $\square$ or $\square$ ) those in summer; $(\nabla)$ those in autumn
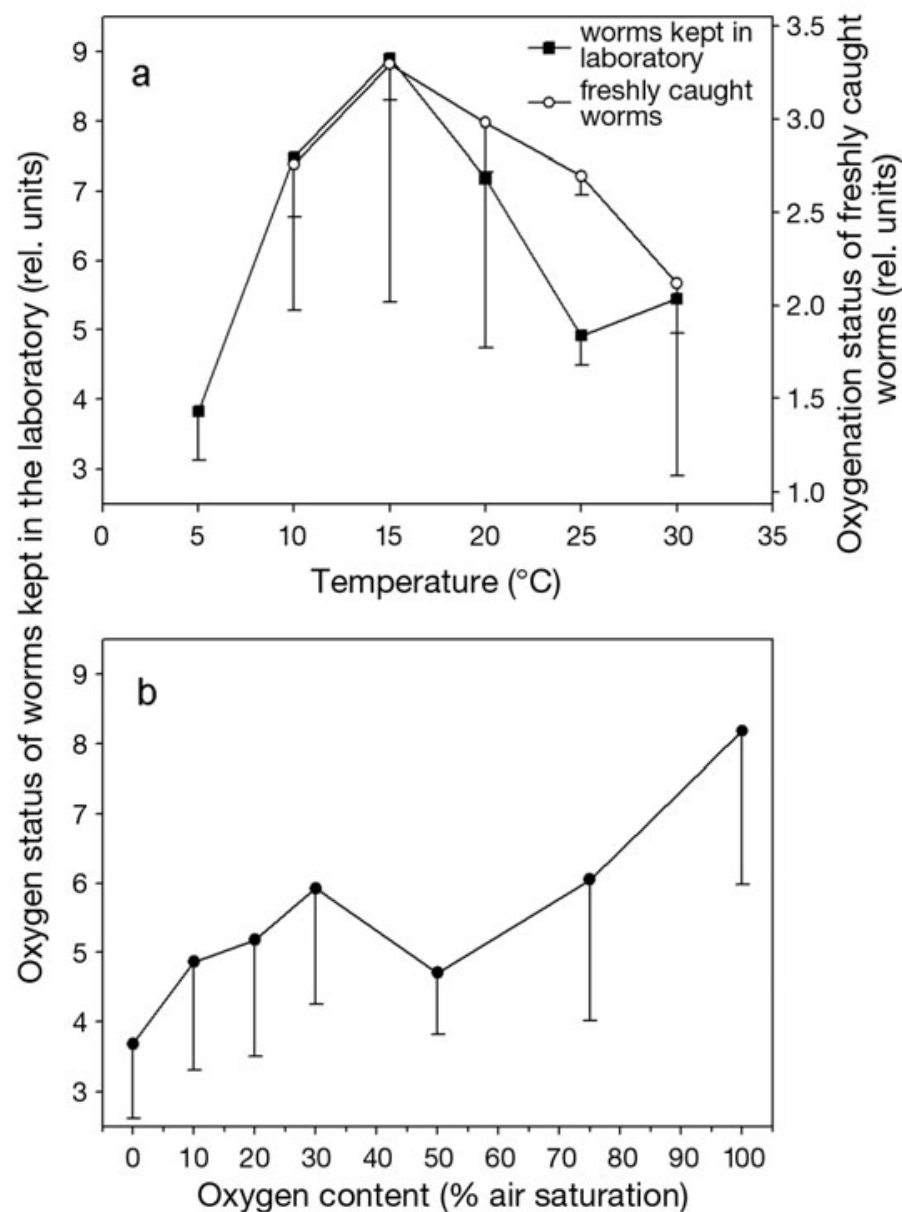

Fig. 5. Arenicola marina. In vivo spectroscopy of lugworms collected in winter near Carolinensiel, Germany. (a) Temperature dependence of apparent oxygenation status measured non-invasively in living lugworms acclimated to $5^{\circ} \mathrm{C}$. Freshly caught lugworms were investigated within $48 \mathrm{~h}$ of their collection in January 2006. For comparison, worms were held in the laboratory for approximately $3 \mathrm{wk}$ at 5 to $7^{\circ} \mathrm{C}$ prior to experimentation. (b) Oxygen dependence of apparent oxygenation measured non-invasively in living lugworms acclimated to $5^{\circ} \mathrm{C}$ and measured at $10^{\circ} \mathrm{C}$. Values are means $-\mathrm{SE}$ ( $\mathrm{n}=3$ individuals)

Comparing spectra obtained from fully oxygenated and deoxygenated individuals at various temperatures results in semi-quantitative information on levels of tissue oxygenation (apparent oxygenation levels) at the respective temperature. Fig. 5a depicts the results from North Sea winter specimens investigated within $48 \mathrm{~h}$ after their collection in January 2006 at Carolinensiel and, for comparison, data from individuals kept in the laboratory for $3 \mathrm{wk}$ at $5^{\circ} \mathrm{C}$. Maximum apparent tissue oxygenation was found at around $15^{\circ} \mathrm{C}$ in both groups, decreasing more or less symmetrically during acute changes towards higher and lower temperatures. In addition, the aerobic state depending on air saturation of the surrounding water was measured in laboratory- 
acclimated individuals at $10^{\circ} \mathrm{C}$ using the same technique (Fig. 5b). A more or less linear increase in apparent tissue oxygenation could be observed with increasing water oxygenation. Data indicate a $P_{\mathrm{c}}$ where oxygen supply becomes insufficient and anaerobic metabolism sets in, at about 20 to $30 \%$ air saturation (4 to $6 \mathrm{kPa}$ ).

\section{DISCUSSION}

\subsection{Critical temperatures estimated by oxygen consumption and in vivo spectroscopy}

The temperature dependence of metabolic rate in the lugworm Arenicola marina seems to be strongly influenced by whether oxygen consumption is analysed in individuals actively irrigating their burrows or in individuals passively exposed to oxygenated water in a respiration chamber (Krüger 1964, Schmidt et al. 1992). The patterns of oxygen consumption in a selfperfused burrow even differed from those seen under conditions when artificial burrows were perfused by a peristaltic pump (Sommer \& Pörtner 2002). Lugworms in open water or in passively perfused burrows would display basal metabolism rather than standard metabolic rate. In most free-ranging ectotherms the latter includes the cost of ventilation, and this is also the case in the present study. For the characterization of the thermal window of a species, it is important to choose a setup in which experimental animals behave in similar ways as under natural conditions. In preliminary experiments, burrow irrigation patterns by lugworms in our experimental setup were not significantly different from those of individuals kept in natural sediment in our rearing system (Wittmann 2005).

In the only study to date of the temperature dependence of metabolic rate in lugworms from the North Sea in winter, Schmidt et al. (1992) found a high $Q_{10}$ of 5 to 10 in the temperature range between 2 and $12^{\circ} \mathrm{C}$ of lugworms acclimated to $4^{\circ} \mathrm{C}$. The $Q_{10}$ between 2 and $8^{\circ} \mathrm{C}$ in our first 2 lugworms collected in early March was similarly high with a value of $15.29 \pm 5.86$. These specimens might therefore represent individuals in a winter state, as in the study by Schmidt et al. (1992). High $Q_{10}$ values reflect a change in the properties of the underlying biochemical systems, such that freeenthalpy barriers of metabolic reactions are increased (Hochachka \& Somero 2002). This may be linked to differences in mitochondrial properties and density between winter- and summer-acclimated lugworms. For example, the mitochondria of winter specimens show a lower sensitivity of proton leakage rate to changes in membrane potential than the mitochondria of summer specimens (Keller et al. 2004, Sommer \&
Pörtner 2004). This leads to a lack in flexibility of metabolic regulation in response to temperature change and may well explain a lower level of heat tolerance in winter (Hawkins 1995). From a more general point of view, setting the free enthalpy of activation of key metabolic processes high was interpreted as a means to downregulate metabolic rate at the expense of a narrowing of thermal windows, as, e.g., in Antarctic stenotherms (Pörtner 2006). Like other polychaetes (Cáceres 1997), lugworms seem to endure winter in a rather dormant state, with low energy demand when food is scarce (Mayes \& Howie 1985, Juretschke \& Kamp 1995, Keller et al. 2004). Their strategy of metabolic downregulation thus resembles the strategy seen in Antarctic ectotherms, at the expense of enhanced stenothermy.

After a relatively short transient warming pulse of $8^{\circ} \mathrm{C}$ for $24 \mathrm{~h}$, the remaining winter lugworms were able to sustain temperatures of up to $23^{\circ} \mathrm{C}$. This reduced sensitivity to temperature change is reflected in a lower $Q_{10}$ of $2.97 \pm 0.88\left(2\right.$ to $\left.17^{\circ} \mathrm{C}\right)$. Extending the range of thermal tolerance and not just shifting the thermal window to higher threshold temperatures may be a reasonable reaction to short-term warming, which could happen in nature at the beginning of springtime. Despite rising environmental temperature, individuals may still periodically be exposed to cold temperatures and have to maintain cold tolerance. If we compare this dataset to those compiled by Krüger (1964) and Schöttler (1989) in lugworms collected in spring, we find similar oxygen consumption values at $14^{\circ} \mathrm{C}$ (ca. $1.5 \mu \mathrm{mol} \mathrm{O} \mathrm{O}^{-1} \mathrm{~g}^{-1}$ ), but no temperature-independent range as observed by Krüger (1964) in individuals exposed to open water. In other invertebrates of the eulittoral, baseline metabolic rate is also kept constant over a wide temperature range, whereas metabolism involving muscular activity responds to temperature (Coyer \& Mangum 1973, Newell \& Bayne 1973, Kristensen 1981). It is worth noting that the standard metabolic rate of our (ventilating) lugworms exposed to transient warming was largely elevated above winter and summer rates, indicating that maintaining cold tolerance in a wide window of thermal tolerance comes at a cost, the cost of cold eurythermy, which is likely associated with reduced activation enthalpies of key metabolic and energy-consuming processes (Pörtner 2006).

Surprisingly, lugworms from the North Sea in summer did not exhibit an increase in metabolic rate over a large temperature range spanning $>10^{\circ} \mathrm{C}$, although they were actively ventilating their burrows. Only when temperatures rose to $>18^{\circ} \mathrm{C}$ did these individuals show an increase in respiration, resulting in a relatively low overall $Q_{10}$ of $2.21 \pm 0.56\left(5\right.$ to $\left.24^{\circ} \mathrm{C}\right)$. Sommer $\&$ Pörtner (2002) recorded a similar yet slightly smaller $Q_{10}$ of $1.67 \pm 0.29\left(-1.7\right.$ to $\left.25^{\circ} \mathrm{C}\right)$ for summer lugworms 
dwelling in perfused burrows. This relatively low sensitivity to temperature is most likely a result of seasonal warm acclimatisation when lugworms, e.g., reduce mitochondrial densities (Keller et al. 2004, Sommer \& Pörtner 2004, see above) and associated metabolic costs. The data also indicate an elimination of the cold tolerance range as a prerequisite for cost reductions in the warmth (cf. Pörtner 2006).

Oxygen supply in different seasonal temperature regimes is likely supported by the observed shifts in the temperature sensitivity of haemoglobin oxygenbinding (Toulmond 1979, cited in Chadwick et al. 1984). We observed higher half-saturation oxygen tensions $\left(P_{50}\right)$ during warm summer months, which will facilitate oxygen release to tissues at elevated oxygen demand and reduced oxygen solubility.

The question arises as to how the present patterns match the emerging picture of oxygen and capacity limitation in the thermal tolerance of aquatic ectotherms (Pörtner 2001, 2002a), which underlies their sensitivity to climate variability and shifts (Pörtner \& Knust 2007). What has not been observed in lugworms before, is a sub-lethal levelling off of metabolic rate at increased temperatures or an overproportional decrease at low temperatures. Arenicola marina reduces metabolic rate under hypoxic conditions as soon as oxygen supply to the cells decreases and before it switches to anaerobic energy production (Toulmond \& Tchernigovtzeff 1984, Kreutzer \& Jue 1997). A large reduction in respiration is visible 2 to $3 \mathrm{~h}$ after the beginning of anaerobiosis (Schöttler et al. 1984). This is likely also the case when anaerobic metabolism is elicited by high or low temperature extremes (Pörtner 2001). In fact, another invertebrate, the cephalopod Sepia officinalis, also displayed an exponential rise of respiration with temperature and a deviation from the $Q_{10}$ relationship when temperatures approached critical values (Melzner et al. 2006a,b).

Similar to Sepia officinalis and other aquatic ectotherms (Pörtner 2001, 2002a), lugworms switch from aerobic to anaerobic metabolism at the borders of their thermal window. Such critical temperatures of lugworms irrigating their natural burrows were previously determined from levels of anaerobic endproducts and intracellular $\mathrm{pH}\left(\mathrm{pH}_{\mathrm{i}}\right)$ in the body wall musculature and led to similar results as those outlined in the present paper (Sommer et al. 1997, Sommer \& Pörtner 2002). In the present study, the drop of mean $P_{\mathrm{EO} 2}$ to below the critical oxygen tension $\left(P_{\mathrm{c}}\right)$ of 4 to $6 \mathrm{kPa}$ at $17^{\circ} \mathrm{C}$ (Schöttler et al. 1983) may indicate that lugworms had reached their critical temperature and initiated anaerobic metabolism (Fig. 2d). Based on these considerations, we suggest that the deviations in oxygen consumption values from an exponential curve mark the temperatures where oxygen limitation sets in and transition to anaerobiosis starts. These temperatures are likely close or equal to lower and upper critical temperatures ( $T_{\mathrm{CI}}$ and $T_{\mathrm{cII}}$ ), respectively (cf. Pörtner 2001). This hypothesis is currently being investigated by in vivo ${ }^{31} \mathrm{P}-\mathrm{NMR}$ experiments, which are aimed to determine critical temperatures under the present experimental conditions.

According to the range of exponential changes in oxygen consumption, the low $T_{\mathrm{cI}}$ in winter specimens from the North Sea may have been between 2 and $-1^{\circ} \mathrm{C}$, while the early levelling off of metabolic rate at $8^{\circ} \mathrm{C}$ may indicate the upper $T_{\text {cII }}$. Corresponding winter specimens studied by Sommer et al. (1997) accumulated acetate at temperatures $<2^{\circ} \mathrm{C}$. While there was no significant increase in anaerobic end-product levels at temperatures as high as $17^{\circ} \mathrm{C}$, metabolic imbalance was indicated by their inability to regulate intracellular $\mathrm{pH}$ at temperatures $<2^{\circ} \mathrm{C}$ and $>10^{\circ} \mathrm{C}$. For North Sea summer specimens, the present $T_{\mathrm{CI}}$ at $5^{\circ} \mathrm{C}$ and $T_{\text {cII }}$ at about $24^{\circ} \mathrm{C}$ would also agree with a previous determination of a $T_{\mathrm{cI}}<5^{\circ} \mathrm{C}$ and a $T_{\text {cII }}>20^{\circ} \mathrm{C}$ (Sommer et al. 1997).

Spectral analysis confirms that the lugworm oxygenation status reflects the oxygen-limited window of thermal tolerance in Fig. 5. Applicability of the technique used is confirmed by the study of hypoxia effects: the $P_{\mathrm{c}}$ of individuals acclimated to $5^{\circ} \mathrm{C}$ and measured at $10^{\circ} \mathrm{C}$ was found at about 20 to $30 \%$ air saturation and an apparent oxygenation status of between 5 and 6 relative units at $10^{\circ} \mathrm{C}$. Schöttler et al. (1983) acclimated lugworms to $8^{\circ} \mathrm{C}$, measured them at $12^{\circ} \mathrm{C}$ and found a similar $P_{\mathrm{c}}$ of 4 to $6 \mathrm{kPa}$. A relatively wide thermal window results from the spectral analyses, thus validating the experimental approach. In the light of the present discussion (see above), these findings also emphasize that future spectral analyses should be elaborated in lugworms dwelling in functional burrows, in order to quantify realistic thermal windows. Passive individuals in fully oxygenated water seem to display wider tolerance windows than actively ventilating lugworms dwelling in burrows.

\subsection{Optimum temperatures estimated by pumping activity and protein biosynthesis}

The pumping frequency, as well as the water volume pumped per peristaltic wave, yields access to the lugworms' optimum temperature $\left(T_{\mathrm{opt}}\right)$ according to pumping efficiency (Fig. 2). The lugworms did not progressively raise pumping frequency up to a limiting temperature as observed by Seymour (1972), but already reached a plateau at $8^{\circ} \mathrm{C}$ (Fig. 2a). Similar to early studies by van Dam (1937), the lugworms regulated their volume flow, not only by adjusting pumping 
frequency, but also by varying the water volume transported by each peristaltic wave of the body wall musculature (wave volume; Fig. 2b). The wave volume was in the same range as in the study by Riisgård et al. (1996), where $3.5 \mathrm{~g}$ worms pumped $0.2 \mathrm{ml}$ at an acclimation temperature of $15^{\circ} \mathrm{C}$. The minimum wave volume was reached at $8^{\circ} \mathrm{C}$, which corresponds to the temperature at which oxygen extraction was most efficient as indicated by the lowest $V_{\mathrm{w}} / M_{\mathrm{O} 2}$ ratio reached at a value of $4.34 \pm 0.34 \mathrm{ml}\left(\mu_{\mathrm{mol} \mathrm{O}}\right)^{-1}$ (Fig. 2c). Similar values were also recorded by Toulmond \& Tchernigovtzeff (1984), Toulmond \& Dejours (1994) and Riisgård et al. (1996) at their respective acclimation temperatures. In conclusion, lugworms at $8^{\circ} \mathrm{C}$ had to pump a minimum volume of water for a given amount of oxygen. We propose this temperature as the temperature of optimum performance, $T_{\text {opt }}$, due to minimal costs of ventilation, which should leave excess energy for other energy consumers, e.g. growth (see below).

The oxygen extraction efficiency of the lugworms decreased slightly beyond critical temperatures in the cold, as well as in the warmth, indicated by a trend of $V_{\mathrm{w}} / M_{\mathrm{O} 2}$ ratio to rise. This might indicate that the extraction of oxygen from water passing a lugworm's body was not optimal any more, as the individuals had to pump more water for a given amount of oxygen. As a consequence, the cost of oxygen supply might have increased, likely linked to a decrease in tissue oxygenation at temperatures lower or higher than acclimation temperature (cf. Fig. 5). Evidently, oxygen supply to tissues is optimal only within a limited thermal range.

According to the concept of oxygen- and capacitylimited thermal tolerance, excess aerobic energy above the baseline of aerobic energy expenditure is only available within the thermal window limited by critical temperatures (Pörtner 2001, 2002a,b). This likely explains why performance follows an asymmetric bell-shaped curve (Angilletta et al. 2002, Pörtner et al. 2004, Pörtner \& Knust 2007). The excess aerobic energy is shared between several processes, possibly taking place at the same time in the body, such as muscular exercise, growth and gamete production. When temperature exceeds pejus values, the amount of excess aerobic energy available for exercise, growth and reproduction is reduced and finally suspended when approaching critical temperatures (Pörtner \& Knust 2007). Here, only processes indispensable for maintenance are retained, as these have first priority in the energy budget (Wieser 1995).

Measurements of growth or of net protein biosynthesis as a process crucial for growth are thus suitable to reveal temperature-dependent performance patterns and, within the thermal tolerance window, the temperature optimum characterized by maximum perfor- mance capacity (Angilletta et al. 2002, Pörtner et al. 2004).

The level of free phenylalanine in the cells of the cuticulo-muscular tube amounts to $0.12 \pm 0.01 \mathrm{nmol}$ $\mathrm{mg}^{-1}$ fresh weight (Siegmund 1982). After injection of the flooding dose of ${ }^{13} \mathrm{C}$-L-phenylalanine, the concentration exceeded this baseline level $>5$-fold already after $30 \mathrm{~min}$. Therefore, it can be concluded that protein biosynthesis was not substrate limited.

In our experiment the maximum protein synthesis rate was found at $6.3^{\circ} \mathrm{C}$ and estimated to be $1.69 \pm$ $0.74 \mathrm{nmol}{ }^{13} \mathrm{C}$-phe $\mathrm{mg}^{-1}$ protein $\mathrm{h}^{-1}$, assuming a baseline ${ }^{13} \mathrm{C}$-phe content of $6.08 \mathrm{nmol}{ }^{13} \mathrm{C}$-phe $\mathrm{mg}^{-1}$ protein (average of all data points without protein synthesis). For comparison, the protein biosynthesis rate in the foot muscle of the land snail Helix apersa was determined to be $0.32 \pm 0.07 \mathrm{nmol} \mathrm{phe} \mathrm{mg}^{-1}$ protein $\mathrm{h}^{-1}$ at 22 to $25^{\circ} \mathrm{C}$ (Pakay et al. 2002). Although the resolution of the NMR spectrometer is limited, the order of magnitude of our data is reasonable for a lower ectothermic invertebrate.

No net protein biosynthesis was detectable at 4 , 14.6 , or at $18.4^{\circ} \mathrm{C}$, indicating that the limits of the thermal window were reached and growth performance was suspended in favour of metabolic maintenance (Pörtner et al. 2004). This is likely due to limited oxygen supply at thermal extremes. Protein synthesis becomes limited at low oxygen tensions in body fluids, as seen in feeding crabs (Mente et al. 2003).

It should be noted that the acute thermal window of protein biosynthesis analysed here is valid for lugworms acclimated to 1 specific acclimation temperature and thus reflects a temperature within ' 1 ' season. This window likely differs from temperature-dependent growth rates traditionally analysed by monitoring body weight or length during long-term incubations of animals over a range of different acclimation temperatures. Any analysis of growth rate, thus, reflects the overall window of growth maxima in various seasons and would include shifting of acute thermal windows between acclimation temperatures. Such data obtained in freshwater crustaceans (Mitchell \& Lampert 2000, Giebelhausen \& Lampert 2001) or fish (Jobling 1997, Pörtner et al. 2004, Pörtner \& Knust 2007) indicate that growth curves exhibit a maximum in the upper temperature range of the thermal window, near the high pejus temperature. This optimum close to the acclimated upper pejus limits would, at the same time, reflect the limited acclimation capacity of the species with respect to temperature.

Our present data on Arenicola marina indicate a maximum of the acute growth performance curve in the lower temperature range of the temperature window, close to lower rather than upper pejus temperature. It remains to be elaborated whether this pattern is 
species specific or characterizes acute versus longterm acclimated windows of growth (see above). This is the first such record of an acute thermal window of protein synthesis and growth capacity in any species. Further studies in other populations of $A$. marina and comparisons of cold- and warm-adapted species should indicate whether this is a general pattern.

With respect to the window of positive growth performance between 4 and $14.6^{\circ} \mathrm{C}$, the thermal window found for Arenicola marina from Brittany in March (Fig. 3) is similar to the one found for individuals collected in March from the North Sea (after exposure to transient warming; cf. Fig. 1). Since both experimental groups were collected in early spring, they might be similar with respect to their physiological status, albeit the acclimation temperature was $5^{\circ} \mathrm{C}$ higher for the population from Brittany. According to maximum efficiency of oxygen extraction from the water, these North Sea specimens displayed a performance optimum close to $8^{\circ} \mathrm{C}$ (Fig. 2). This finding corresponds well with the 'growth' optimum of individuals from Brittany found at $6.3^{\circ} \mathrm{C}$ and supports the conclusion that acute growth capacity is maximal close to lower pejus temperature.

\section{CONCLUSIONS}

Further study will be needed to elaborate a more continuous picture of shifts in acute performance windows and performance levels during progressive acclimatisation throughout the year and also to compare these windows and the resulting performance levels in populations of Arenicola marina in a latitudinal cline. The present results indicate and confirm that such measures closely relate to, and are influenced by, the ambient temperature regime, depending on the season and according to local climate conditions. Such studies will provide information on the climate-related dependence of physiological and ecological performance and, thus, contribute to an understanding of the survival, relative success and evolution of species under various climatic conditions and in response to climate change (Pörtner 2004, 2006, Pörtner et al. 2005b, Pörtner \& Knust 2007).

Acknowledgements. This work was supported by grants from the Deutsche Forschungsgemeinschaft (Aquashift Po 278/11 and $\mathrm{Pa}$ ). The experiments described here comply with the current laws of the country in which they were performed. We thank E. Laturnus for his work on in vivo spectroscopy of Arenicola marina and the Marine Biological Stations Arcachon and Roscoff, France, for their helpful support. Special thanks go to R. Wittig for NMR data processing and giving great advice on all computer-related questions, as well as to B. Klein and all other helpers for digging lugworms and carrying tons of sediment.

\section{LITERATURE CITED}

Angel MV (1991) Variations in time and space: Is biogeography relevant to studies of long-time scale change? J Mar Biol Assoc UK 71:191-206

Angilletta MJ, Niewiarowski PH, Navas CA (2002) The evolution of thermal physiology in ectotherms. J Therm Biol 27:249-268

Bradford MM (1976) A rapid and sensitive method for the quantitation of microgram quantities of protein utilizing the principle of protein-dye binding. Anal Biochem 72: $248-254$

Cáceres CE (1997) Dormancy in invertebrates. Invertebr Biol 116:371-383

Chadwick RA, Barrow MJ, Wells RMG (1984) Aspects of respiratory function on the blood of the intertidal lugworm Abarenicola affinis (Polychaeta). NZ J Mar Freshw Res 18:171-175

Coyer PE, Mangum CP (1973) Effect of temperature on active and resting metabolism in polychaetes. In: Wieser W (ed) Effects of temperature on ectothermic organisms. Ecological implications and mechanisms of compensation. Springer, Berlin, p 173-180

Giebelhausen B, Lampert W (2001) Temperature reaction norms of Daphnia magna: the effect of food concentration. Freshw Biol 46:281-289

> Hawkins AJS (1995) Effects of temperature change on ectotherm metabolism and evolution: metabolic and physiological interrelations underlying the superiority of multilocus heterozygotes in heterogeneous environments. J Therm Biol 20:23-33

Hochachka PW, Somero GN (2002) Biochemical adaptation: mechanisms and processes in physiological evolution. Chapter 7: Temperature. Oxford University Press, New York, p 290-449

Hummel H, Sommer AM, Bogaards R, Pörtner HO (1997) Variation in genetic traits of the lugworm Arenicola marina: Temperature related expression of mitochondrial allozymes? Mar Ecol Prog Ser 159:189-195

Jobling M (1997) Temperature and growth: modulation of growth rate via temperature selection. In: Wood CM, MacDonald DG (eds) Global warming. Implications for freshwater and marine fish. Cambridge University Press, Cambridge, p 225-253

Johnston IA, Bennett AF (eds) (1996) Animals and temperature: phenotypic and evolutionary adaptation. Cambridge University Press, Cambridge, p 53-57

Juretschke HP, Kamp G (1995) In vivo nuclear magnetic resonance studies on the lugworm Arenicola marina. II. Seasonal changes of metabolism. J Comp Physiol 165B: 153-160

Keller M, Sommer AM, Pörtner HO, Abele D (2004) Seasonality of energetic functioning and production of reactive oxygen species by lugworm (Arenicola marina) mitochondria exposed to acute temperature changes. J Exp Biol 207:2529-2538

Kreutzer U, Jue T (1997) Metabolic response in Arenicola marina to limiting oxygen as reflected in the ${ }^{1} \mathrm{H}-\mathrm{NMR}$ oxymyoglobin signal. Eur J Biochem 243:233-239

Kristensen E (1981) Direct measurement of ventilation and oxygen uptake in three species of tubiculous polychaetes (Nereis spp.). J Comp Physiol 145:45-50

Krogh-Rasmussen K, Weber RE (1979) Respiratory properties of erythrocruorin (extracellular haemoglobin) in the blood of the annelid Arenicola marina with special reference to the influences of salinity and temperature. Ophelia 18: $151-170$ 
Krüger F (1964) Versuche zur Abhängigkeit der Atmung von Arenicola marina (Annelides Polychaeta) von Größe und Temperatur. Helgol Wiss Meeresunters 10:38-63

Langenbuch M, Bock C, Leibfritz D, Pörtner HO (2006) Effects of environmental hypercapnia on animal physiology: a ${ }^{13} \mathrm{C}$ NMR study of protein synthesis rates in the marine invertebrate Sipunculus nudus. Comp Biochem Physiol A 144:479-484

Lannig G, Eckerle L, Serendero I, Sartoris FJ and others (2003) Temperature adaptation in eurythermal cod (Gadus morhua): a comparison of mitochondrial enzyme capacities in boreal and Arctic populations. Mar Biol 142: 589-599

Mangum CP (1978) Temperature adaptation. In: Mills PJ (ed) Physiology of annelids. Academic Press, London, p 447-478

Mayes E, Howie DID (1985) Biochemical composition and sediment temperature in relation to the reproductive cycle in the lugworm Arenicola marina. Neth J Sea Res 19:111-118

Melzner F, Bock C, Pörtner HO (2006a) Critical temperatures in the cephalopod Sepia officinalis investigated using in vivo ${ }^{31} \mathrm{P}$ NMR spectroscopy. J Exp Biol 209:891-906

Melzner F, Bock C, Pörtner HO (2006b) Temperature dependent oxygen extraction from the ventilatory current and the costs of ventilation in the cephalopod Sepia officinalis. J Comp Physiol B 176:607-621

Mente E, Legeay A, Houlihan DF, Massabuau JC (2003) Influence of oxygen partial pressure in protein synthesis in feeding crabs. Am J Physiol 284:R500-R510

Mitchell SE, Lampert W (2000) Temperature adaptation in a geographically widespread zooplankter, Daphnia magna. J Evol Biol 13:371-382

> Newell RC, Bayne BL (1973) A review on temperature and metabolic acclimation in intertidal marine invertebrates. Neth J Sea Res 7:421-433

Nielsen EE, Hansen MM, Schmidt C, Meldrup D, Gronkjaer P (2001) Population of origin of Atlantic cod. Nature 413: 272

Pakay JL, Withers PC, Hobbs AA, Guppy M (2002) In vivo downregulation of protein synthesis in the snail Helix apersa during estivation. Am J Physiol Regul Intergr Comp Physiol 283:R197-R204

Perry AL, Low PJ, Ellis JR, Reynolds JD (2005) Climate change and distribution shifts in marine fishes. Science 308:1912-1915

Pörtner HO (2001) Climate change and temperature-dependent biogeography: oxygen limitation of thermal tolerance in animals. Naturwissenschaften 88:137-146

Pörtner HO (2002a) Climate variations and the physiological basis of temperature dependent biogeography: systemic to molecular hierarchy of thermal tolerance in animals. Comp Biochem Physiol A 132:739-761

Pörtner HO (2002b) Physiological basis of temperature dependent biogeography: tradeoffs in muscle design and performance in polar ectotherms. J Exp Biol 205: 2217-2230

Pörtner HO (2002c) Environmental and functional limits to muscular exercise and body size in marine invertebrate athletes. Comp Biochem Physiol A 133:303-321

Pörtner HO (2004) Climate variability and the energetic pathways of evolution: the origin of endothermy in mammals and birds. Physiol Biochem Zool 77:959-981

> Pörtner HO (2006) Climate dependent evolution of Antarctic ectotherms: an integrative analysis. Deep-Sea Res II 53: 1071-1104

Pörtner HO, Knust R (2007) Climate change affects marine fishes through the oxygen limitation of thermal tolerance. Science 315:95-97

Pörtner HO, Berdal B, Blust R, Brix O and others (2001) Climate induced temperature effects on growth performance, fecundity and recruitment in marine fish: developing a hypothesis for cause and effect relationships in Atlantic cod (Gadus morhua) and common eelpout (Zoarces viviparus). Cont Shelf Res 21:1975-1997

Pörtner HO, Mark FC, Bock C (2004) Oxygen limited thermal tolerance in fish? Answers obtained by nuclear magnetic resonance techniques. Respir Physiol Neurobiol 141: $243-260$

Pörtner HO, Lucassen M, Storch D (2005a) Metabolic biochemistry: its role in thermal tolerance and in the capacities of physiological and ecological function. In: Farrell AP, Steffensen JF (eds) The physiology of polar fishes. Fish Physiol 22:79-154

Pörtner HO, Storch D, Heilmayer O (2005b) Constraints and trade-offs in climate dependent adaptation: energy budgets and growth in a latitudinal cline. Sci Mar 69(Suppl 2):271-285

Riisgård HU, Berntsen I, Tarp B (1996) The lugworm (Arenicola marina) pump: characteristics, modelling and energy cost. Mar Ecol Prog Ser 138:149-156

Rousselot M, Le Guen D, Chabasse C, Zal F (2006) Novel dissociation mechanism of a polychaetous annelid extracellular hemoglobin. FEBS J 273:1582-1596

Schmidt R, Schiedek D, Schöttler U (1992) Der Einfluss der Temperatur auf den anaeroben Energiestoffwechsel von Arenicola marina L. (Polycheata). Verh Dtsch Zool Ges 85: 167

Schöttler U (1989) Anaerobic metabolism in the lugworm Arenicola marina during low tide: the influence of developing reproductive cells. Comp Biochem Physiol A 92:1-7

Schöttler U, Wienhausen G, Zebe E (1983) The mode of energy production in the lugworm Arenicola marina at different oxygen concentrations. J Comp Physiol 149:547-555

Schöttler U, Wienhausen G, Westermann J (1984) Anaerobic metabolism in the lugworm Arenicola marina L.: the transition from aerobic to anaerobic metabolism. Comp Biochem Physiol B 79:93-103

Seymour MK (1972) Effects of temperature changes on irrigation rate in Arenicola marina. Comp Biochem Physiol A 43:553-564

Siegmund B (1982) Die Bedeutung der freien Aminosäuren für den anaeroben Stoffwechsel von Arenicola marina L. Diploma thesis, Heinrich-Heine-Universität Düsseldorf

Sokolova IM, Pörtner HO (2003) Metabolic plasticity and critical temperatures for aerobic scope in a eurythermal marine invertebrate (Littorina saxatilis, Gastropoda: Littorinidae) from different latitudes. J Exp Biol 206:195-207

> Sommer AM, Pörtner HO (1999) Exposure of Arenicola marina to extreme temperatures: adaptive flexibility of a boreal and a subpolar population. Mar Ecol Prog Ser 181: 215-226

> Sommer AM, Pörtner HO (2002) Metabolic cold adaptation in the lugworm Arenicola marina (L.): comparison of a White Sea and a North Sea population. Mar Ecol Prog Ser 240: 171-182

Sommer AM, Pörtner HO (2004) Mitochondrial function in seasonal acclimatization versus latitudinal adaptation to cold in the lugworm Arenicola marina (L.). Physiol Biochem Zool 77:174-186

Sommer AM, Klein B, Pörtner HO (1997) Temperature induced anaerobiosis in two populations of the polychaete worm Arenicola marina (L.). J Comp Physiol B 167:25-35 Toulmond A (1977) Temperature-induced variations of blood 
acid-base status in the lugworm, Arenicola marina (L.). I. In vitro study. Respir Physiol 31:139-149

Toulmond A (1979) Action du pH et de la température sur l'affinité pour l'oxygène de l'hémoglobine de Arenicola marina (L.), Annélide Polychète. Vie Milieu 29:443-459

Toulmond A, Dejours P (1994) Energetics of the ventilatory piston pump of the lugworm, a deposit-feeding polychaete living in a burrow. Biol Bull 186:213-220

Toulmond A, Tchernigovtzeff C (1984) Ventilation and respiratory gas exchange of the lugworm Arenicola marina (L.) as a function of ambient $\mathrm{pO}_{2}$ (20-700 Torr). Respir Physiol 57:349-363

van Dam L (1937) Über die Atembewegungen und das Atemvolumen von Phyrganea-Larven, Arenicola marina

Submitted: November 2, 2007; Accepted: March 31, 2008 und Nereis virens. Zool Anz 118:122-128

Weber RE (1978) Respiratory pigments. In: Mills PJ (ed) Physiology of annelids. Academic Press, London, p 393-446

Wells GP (1964) Temperature, taxonomic technique and the zoogeography of lugworms (Arenicolidae, Polychaeta). Helgol Wiss Meeresunters 10:404-410

Wieser W (1995) Energetics of fish larvae, the smallest vertebrates. Acta Physiol Scand 154:279-290

Wittmann AC (2005) Bestimmung des sauerstofflimitierten Temperaturtoleranzfensters beim Wattwurm Arenicola marina L. Diploma thesis, University of Bremen

Wood CM, MacDonald DG (eds) (1997) Global warming. Implications for freshwater and marine fish. Cambridge University Press, Cambridge

Proofs received from author(s): September 4, 2008 